\title{
線状加熱にお污る衝突噴流火炎場の燃焼解析法に関する 研究
}

\author{
学生員 澤村潡 司* 正員 富田康光 ${ }^{*}$ \\ 正員大沢直樹* 正員 橋本聖史* \\ 正員新海信 隆 ${ }^{* *}$
}

Study on Combustion Analysis in the Impinging Jet Flame during Line Heating Process

by Junji Sawamura, Student Member Yasumitsu Tomita, Member Naoki Osawa, Member Kiyoshi Hashimoto, Member

Nobutaka Shinkai, Member

\section{Summary}

In order to analyze heat flow in the impinging combustion flame which is generated during line heating process, a 3-dimensional computer program has been developed.

Reduced reaction mechanism model and Mixing combustion model are employed in this program.

It is found that the calculated gas temperature distribution in the flame is in agreement with the experimental one except the peak temperature of center part of the flame when Mixing combustion model is employed.

\section{1. 緒 言}

船体外板は複矱な 3 次元曲面で構成されている。そその 形状は線状加熱と呼ばれる造船業特有の工程によって, 熟練技能者の経験と勘を頼りに作り出されている。近 年，造船業の国際競争力を高めるため，線状加熱作業の 自動化による高効率化の実現が強く求められている。 そ のためには，ガス加熱に伴う物理現像を理論的に解析し， 加熱条件と板の変形量の関係を明らかし，目標形状を得

* 大阪大学大学院工学研究科

** ビューロベリタスジャパン

原稿受理 平成 13 年 7 月 10 日

秋季講演会に扔いて講演 平成 13 年 11 月 $15 ， 16$ 日
るための最適加熱条件を決定する手法を確立寸る必要が ある。

ガス加熱による物理現象のうち，鋼板内の熱伝導と 熱弹塑性変形については, 上田ら ${ }^{11}$, 石山ら ${ }^{21}$, 野本ら 3)4)により，解析方法が示され，目標形状に必要な入熱 量分布の推定が可能になりつつある. 一方，ガスの燃焼 熱流動，ガスと鋼板との熱伝達に関しては未解明な点が 多い: 辻ら ${ }^{5)}$, 封崎ら ${ }^{6)}$ が実験的にガスから鋼板への入 熱量を推定才る方法を示しているが，その成果は特定の 加熱条件に限定したものであり，任意の加熱条件で入熱 量を推定できない，自動化を見据えた解析には，任意の 加熱条件で入熱量を推定才る解析手法を確立寸る必要が あるが，現在そのような解析手法は存在しない，それ在 可能に寸るには，ガスの燃焼および流動形態，ガスと䤱 鈑との間の熱伝澾現象の解明が必要である. 
線状加熱でのガス流場は高速下で火炎が銅板に衝突寸 万衝突噴流火炎場となる。このような燃炧流場の燃焼解 析法, 熱伝達率推定法は著者らの知る限り未だ開発され ていない，著者らは既報〕に执いて，加熱ガ入の燃焼流

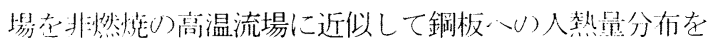
推定小万方法老提案し, 点加熱試験結果と比較しその妥 当性在示した.

こひ提案した解析法は，加熱条件が大幅に変打ると非 燃焼ガ入の噴出条件を実験結果又は，㛜密な解析結果を 用いて再検討寸る必要がある。衝突噴流火炎場つ温度場 計測には多大な実験費用を要し, 多数回実験を繰り返寸 ことは現実的ではない，そこで，高温ガスの火口境界条 件設定方法を定式化することを目的に，既報 ${ }^{819)}$ におい て衝乫噴流火炎場の解析を行った。これら燃焼解析によ り衝突噴流火炎場の定性的性質, 火口境界条件の違い上 る燃焼場の変化を知ることができた。

燃焼現象は非線形性の強い現象であり，化学反忘と流 体運動が並行して起こる複雑な現象であるため, その現 象の解明と予測は困難であった。近年, 実験計測装置の 性能向上, 解析方法の発達により火炎構造の細かな部分 まで解明されつつある。しかし, 複雑な燃焼場を精度良 く推定寸るためには, 解析に必要な構成式を短い時間ス テップで，小さい計算格子で解く必要があるが，燃暁反 応に現れる化学種の数は極めて多く, 寸べての保存方程 式を十分短い時間ステップと, 空間分解能で解く事は実 用計算では難しい，また，高速で衝突する噴流火炎場に 関寸る研究例は実験, 解析ともになく, その燃焼現象の 詳細は不明であり, 数值解析方法も確立されていない.

既報 ${ }^{899)}$ の解析では，上記のような理由から，燃焼モ デルに乱流場での燃焼状態を表現するために考案された, 総括一段の渦消散モデル ${ }^{12)}$ を, 乱流モデルに $k-\varepsilon 2$ 方程 式の標準モデル ${ }^{13)}$ を用い, 衝突噴流場の定性的性質を 解析により推定寸ることができた。しかし，この解析が 定量的に温度場, 速度場を推定できているか怀明であ

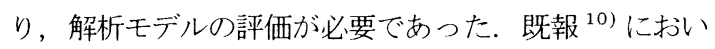
て, 高性能 LIF 計測装置を用いることにより, 衝突噴流 火炎の温度分布の過渡変化の計測に成功し, 鋼板表面直 近までの温度場の詳細を知ることができ, ガス流場は鋼 板の温度上昇に関わらず，極めて短い時間で定常になる ことがわかった.

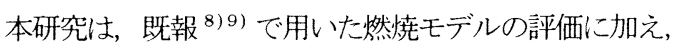
現在考案されている燃焼モデルのうち, 比較的単純なモ デルを用いた計算が，どの程度計算で実験の現象を予測 できるかを調べるため, 乱流予混合衝突噴流火炎の数值 解析を行い, 既報の実験 ${ }^{10)}$ と比較した。 そして, 燃焼 モデルの違いによる温度場の変化を示し, 衝突噴流火炎 の燃焼状態に関しての考察を行う。

\section{2. 計算理論}

\section{1 熱流動計算}

対象と才る火炎は，正少形ノズルから予混合ガス燃料 を噴出し，它心燃粖燃㹸に上り形成される乱流予混命 火炎である。支煺方科式流、密度加重平均を施した連続 の式, 運動方程式, ェネルギー方程式, 乱流モデルのた

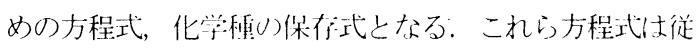
属変数を $\phi$ で代表させると, 非汗縮流体, 定常乱流場, 3 次元直交座標系を用いた場合，次式で表寸ことができる。

$$
\begin{array}{r}
\frac{\partial}{\partial x}(\bar{\rho} \widetilde{u} \phi)+\frac{\partial}{\partial y}(\bar{\rho} \widetilde{v} \phi)+\frac{\partial}{\partial z}(\bar{\rho} \widetilde{w} \phi) \\
-\frac{\partial}{\partial x}\left(\Gamma \frac{\partial \phi}{\partial x}\right)-\frac{\partial}{\partial y}\left(\Gamma \frac{\partial \phi}{\partial y}\right)-\frac{\partial}{\partial z}\left(\Gamma \frac{\partial \phi}{\partial z}\right)=S_{\phi}
\end{array}
$$

従属変数 $\phi$ として, 具体的には $\mathrm{x}, \mathrm{y}, \mathrm{z}$ 方向速度成分, $\widetilde{u}, \widetilde{v}$ おび, $\widetilde{w}$, エンタルピー $\widetilde{h}$, 乱れエネルギー $\bar{k}$ と その消散率 $\bar{\varepsilon}$, 反応に関係寸る化学種の質量分率 $\widetilde{m}_{i}$ で ある.〜はFavre平均，一は時間平均を表し， $\rho$ は密度， $\Gamma$ は拡散係数, $S_{\phi}$ は生成項である.

乱流モデルには $k-\varepsilon 2$ 方程式の標準モデル ${ }^{13)}$ を採用し ている. 密度 $\rho$ は完全ガスの状態方程式から求めた。各 成分および多成分系の粘性係数 $\mu$, 比熱 $C_{p}{ }^{15) 14)}$ は温度, 成分濃度による变化を考えた。

\section{2 燃焼計算}

燃焼による発熱はエンタルピー $h$ 在次式のように感エ ンタルピー $h_{j}$ と生成エンタルピー $h_{j}^{0}$ の和と表し, 燃焼 反応による化学種組成の変化に応じた比熱, 生成エンタ ルピーを与えることにより表現される。

$$
\begin{aligned}
h & =\sum_{j=1}^{n} m_{j}\left(h_{j}+h_{j}^{0}\right) \\
& =\int_{T_{0}}^{T} \sum_{j=1}^{n} m_{j} C_{p_{j}} d T+\sum_{j=1}^{n} m_{j} h_{j}^{0}
\end{aligned}
$$

燃焼による各化学種の生成, 消滅は (1) 式の化学種保存 式の生成項により表される。 これを表現寸るものが燃焼 反応モデルと呼ばれるものである。

\subsection{1燃焼反応モデル}

炭化水素系燃料が完全燃焼寸る時の反応式は次式で表 せる.

$$
\text { Fuel }+\mathrm{aO}_{2} \rightarrow \mathrm{bCO}_{2}+\mathrm{cH}_{2} \mathrm{O}
$$

これは反応のはじめの状態と終わりの状態を表現してい るだけで，途中に起こる現象は全く表現されていない. この反応式を総括一段反応式という. 
実際には火炎面と呼ばれろ非常に薄い領域内で，極め て短い時間に，数十という多数の素反応が同時にあるい は順次抗こり，最終的に(3) 式で表せる反応が起こって いるように見える。本た，装父志付周囲の状態により 順反応だけでなく䢟父忍寺，起こり反忘式はさらに複雑に なる。

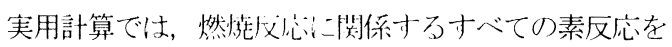
細か心時間ステッフで，小さい䣋算格子を用いて解くこ とは難しく，その一部け仅忍在取り出し，ある仮定及び 簡略化を用いた燃焼反心忍デルを用い燃焼現象を表現才 る. 現在考案されているモ゙ラ゙ルの中で，才べての燃焼現 象を精度よく表現できるモデルはなく，解析対象に対し て適切なモデルを選択寸るか新しい燃焼モデルを開発す る必要がある.

解析対象である衝突噴流火炎場の反応機構の詳細は解 明されておらず, 中間生成物の発生等, 燃焼に関与寸る 化学種を考慮した多段の化学反応を考えても, よ゙の化学 種, どの反応が衝突燃燒場で生じているのかわからない. 本研究の目的から見れば, 詳細な化学反忘を解き, 中間 生成物の発生等の詳細な火炎構造がわかるよりも，解析 の容易な簡単なモデルで, 解析領域の温度分布が得られ ればよい.

そこで，既報 ${ }^{819)}$ で用いた燃焼モデルの評価を含め, 以下に示才比較的解析の容易な $2 つ$ モデルを用いて乱 流予混合衝突噴流火炎の数值解析を行い，既報の実験 ${ }^{10)}$ で得られた火炎温度分布を用いて，どの程度計算で，実 験の現象を予測できるかを調べる.

以下，解析で用いた燃焼モデルについて説明する。

\subsection{2 化学反応速度支配のモデル}

化学種 $j \omega$ 単位時間, 单位体積当りの生成速度 $R_{j}$ は 一般的に次式で与えられる。

$$
R_{j}=M_{j} \sum_{i=1}^{m}\left(\nu_{j, i}-\nu^{\prime}{ }_{j, i}\right) k_{i} \prod_{i=1}^{s}\left[C_{j}\right]
$$

ただし， $\nu_{j, i}, \nu{ }_{j, i}$ は反応 $i$ における化学種 $j$ の反応 物, 生成物の量論係数, $k_{i}$ 㳉反応 $i$ の反応速度定数であ る. 反応は各素反応に执て，正逆反応をそれぞれ別の 反応と考える. $\left[C_{j}\right]$ は化学種 $j$ のモ儿濃度, $M_{j}$ は化学 種 $j$ の分子量, $\mathrm{m}$ は反忍の数, $\mathrm{s}$ は化学種の数である.

反応 $i$ の正方向速度定数 $k_{i}^{f}$ は次のアレニウスの表示 式で与えられる。

$$
k_{i}^{f}=A T^{n} \cdot \exp \left(\frac{-E}{R T}\right)
$$

ここで，A，n，E快垁験定数であり，Eは反応の活性化 エネルギーである，逆反忘の反応速度定数 $k_{i}^{r}$ は，正方
Table 1 Forward rate constants of the global reaction scheme for methan (as $A T^{b} e^{(-E / R T)}$ )

\begin{tabular}{ccccc}
\hline $\begin{array}{c}\text { Reac } \\
\text { tion }\end{array}$ & $\begin{array}{c}\text { Rate con } \\
\text { stant }\end{array}$ & A & b) & $\begin{array}{c}\text { E } \\
(\mathrm{cal} / \mathrm{mol})\end{array}$ \\
\hline$(a)$ & $k_{a}^{f}$ & $0.44 \times 10^{12}$ & 0 & 30000 \\
$(b)$ & $k_{b}^{f}$ & $0.30 \times 10^{9}$ & 0 & 30000 \\
$(c)$ & $k_{c}^{f}$ & $0.68 \times 10^{16}$ & -1 & 40000 \\
$(d)$ & $k_{d}^{f}$ & $0.275 \times 10^{10}$ & 0 & 20000 \\
\hline
\end{tabular}

向の反応速度定数 $k_{i}^{f}$ とその反応の平衡定数 $K_{i}$ から求 める.

火炎構造を峳密にシミュレート寸るには，燃焼過程で 現れる寸べての化学種に対して，(1) 式の化学種保存式 拉ざ上記 (4),(5) 式を解かなければならない，実用燃 焼計算では，燃焼反応に関係するすべての素反応掞よび 反応式を扱うことは難しく，簡略化が必要になる。

(1)Reduced Reaction model

詳細反応の中から一部の反応を取り出したり，早い素 反応の部分平衡を仮定しながら，いくつかの素反応を組 み合わせて見かけの反応系を作り出寸ことにより燃焼反 応を簡略化寸る。

Jones $5^{17)}$ は 6 種類の化学種と 4 段の素反応を取り 出し, 燃焼反応をモデル化している.

$$
\begin{array}{ll}
\text { (a) } \mathrm{C}_{n} \mathrm{H}_{2 n+2}+\frac{n}{2} \mathrm{O}_{2} & \rightarrow n \mathrm{CO}+(n+1) \mathrm{H}_{2} \\
\text { (b) } \mathrm{C}_{n} \mathrm{H}_{2 n+2}+n \mathrm{H}_{2} \mathrm{O} & \rightarrow n \mathrm{CO}+(2 n+1) \mathrm{H}_{2} \\
(c) \mathrm{H}_{2}+\frac{1}{2} \mathrm{O}_{2} & \leftrightarrow \mathrm{H}_{2} \mathrm{O} \\
(\text { d }) \mathrm{CO}+\mathrm{H}_{2} \mathrm{O} & \leftrightarrow \mathrm{CO}_{2}+\mathrm{H}_{2}
\end{array}
$$

この時, 各反応の正方向（右向き）の反応速度は次式 のように表される.

$$
\begin{aligned}
& \text { (a) } r_{(a)}^{f}=k_{a}^{f}\left[\mathrm{C}_{n} \mathrm{H}_{2 n+2}\right]^{\frac{1}{2}}\left[\mathrm{O}_{2}\right]^{\frac{5}{4}} \\
& \text { (b) } r_{(b)}^{f}=k_{b}^{f}\left[\mathrm{C}_{n} \mathrm{H}_{2 n+2}\right]\left[\mathrm{H}_{2} \mathrm{O}\right]^{\frac{5}{4}} \\
& \text { (c) } r_{(c)}^{f}=k_{c}^{f}\left[\mathrm{H}_{2}\right]^{\frac{1}{4}}\left[\mathrm{O}_{2}\right]^{\frac{3}{2}} \\
& (d) \quad r_{(d)}^{f}=k_{d}^{f}[\mathrm{CO}]\left[\mathrm{H}_{2} \mathrm{O}\right]
\end{aligned}
$$

$\mathrm{n}=1$, 才なわちメタンガス $\left(\mathrm{CH}_{4}\right)$ の場合の (6) 式で 用いる定数を Table1に示寸. 反応 (a), (b) は正方向の みの反忘が考慮されるが, 反応 (c), (d) は平衡反応であ り, 正逆方向の反応が考慮される. 逆反応速度定数は正 方向の反応速度と平衡定数の比により求める. 


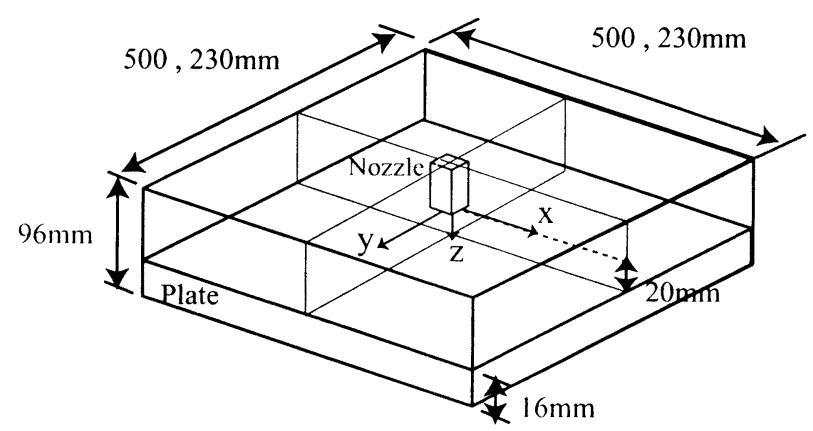

(a) Geometry for the numerical analysis

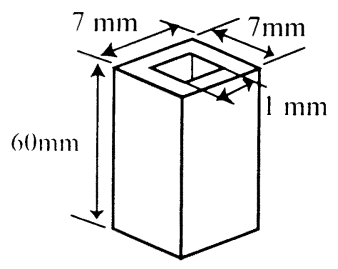

(b) Configuration of Nozzle

Fig. 1 Geometry for numerical analysis and configuration of nozzle

\subsection{3 乱流混合速度支配のモデル}

乱流場にいおいては，化学反応速度が律速とならなず， 乱流場を対象とした燃焼モデルが考案されている。

(1) 渦消散モデル

燃料のガス塊と酸化剤，既然ガス塊が崩壊して分子ス ケールの混合に達したときに燃焼反応が起こると考える. その反応速度は乱れの渦が微少な渦に崩壊し消散寸る速 度, 寸なわち乱れエネルギーの減衰速度 $\varepsilon / \kappa$ に比例寸る. 乱流予混合火炎の場合，燃料，酸化剂，既然ガス魂の消 散速度に比例して反応が起こるとして，燃料の反応速度 $\left(\mathrm{kmol} / \mathrm{m}^{3} / \mathrm{s}\right)$ は次式で表せる。 ${ }^{16)}$

$$
\bar{R}_{f u}=A\left(\frac{\bar{\rho} \varepsilon}{\kappa}\right) \cdot \min \left(\widetilde{m}_{f u} ; \frac{\widetilde{m}_{o x}}{i} ; B \frac{\widetilde{m}_{p r}}{1+i}\right)
$$

ここで $k ， \varepsilon$ は乱れエネルギーとその消散率，i は量 論酸素燃料比, $\tilde{m}_{f u}, \tilde{m}_{o x}, \tilde{m}_{p r}$ はそれぞれ燃料, 酸化剤, 既燃ガスの質量分率， $\mathrm{A}, \mathrm{B}$ は $\mathrm{A}=4, \mathrm{~B}=0.5$ なる経験定 数である。

\subsection{4 化学反応速度と乱流混合速度を組み合わせたモ デル}

化学反応速度支配のモデルは, 乱流燃焼の特性を表現 できない，一方，乱流混合支配モデルは化学反応支配の 火炎構造を表現できない：このため，二つの特性をもつ ような燃焼器では両者の構造を考慮したモデルを用いて 計算を行う必要がある。しかし、これら両方の特性を表 現できる確立されたモデルは見当たらない，実用計算で は両者の性質を表現した燃焼モデルを組み合わせて用い ることが多く, 本解析でも上記の化学反応律則モデルと 乱流混合速度支配モデルを組み合わせたモデルを用いる。

(1) 化学反応速度と渦消散モデル

乱流場では, 燃料, 酸化剂および既然ガスが崩壊, 分 子レベルまで混合し、その後, 化学反応で然焼才ると考 えられる. そのため, 乱流燃焼速度 $R_{c}$ は化学反応速度
$R_{k}$ と乱流混合速度 $R_{m}$ のうち，小さいものに支配され ると考え，次式のように与えられる。

$$
R_{c}=\min \left(R_{k}, R_{m}\right)
$$

本解析では, Jones らいの の 4 段簡略化モデルと Magnussen $5^{12)}$ の渦消散モデルを組み合わせ，解析を行っ

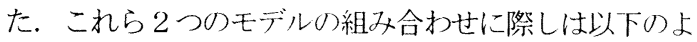
うな考えを取り入れた。 ${ }^{11}$. 平衡反応を考える場合, 化 学種はその時の燃焼場の状況に忘じて, 燃料, 酸化剂, 既然ガスのどれにもなりうることから，乱流混合速度は 反応に関扔る化学種を独立したガス魂と考え，その消散 速度に比例寸ると考える。

$$
\mathrm{aA}+\mathrm{bB} \rightarrow \mathrm{cC}+\mathrm{dD}
$$

なる反応式で表現される燃焼反応に対して，乱流混合速 度は次のように表せる。

$$
R_{m j}=4.0\left(\frac{\bar{\rho} \varepsilon}{\kappa}\right) \cdot \min \left(\frac{\tilde{m}_{A}}{a} ; \frac{\tilde{m}_{B}}{b} ; \frac{\tilde{m}_{C}}{c} ; \frac{\tilde{m}_{D}}{d}\right)
$$

また, 反応の方向は化学反匛によって決まり, 乱流混 合には支配されないとし，化学反応速度 $R_{k j}(\mathrm{j}$ は化学反 応番号) を下式で与えう。

$$
R_{k j}=r_{j}^{f}-r_{j}^{k}
$$

ここで， $r_{j}^{f}$ は正方向反店速度， $r_{j}^{k}$ 逆反応速度を表寸.

したがって，然焼反念速度は下式であたえられる。

$$
R_{c j}=\frac{R_{k j}}{\left|R_{k j}\right|} \min \left(\left|R_{k j}\right|, R_{m j}\right)
$$




\section{3. 数值計算}

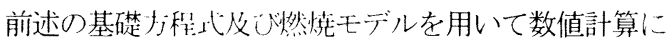
より，流速，温度，化湫湜度などを算出寸る。支配方 程式の離散化にはトニントロールボリュームに基づく有限

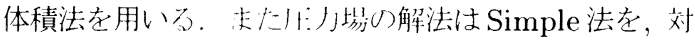

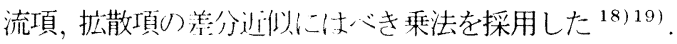

乱流モデルは $k-\varepsilon 2)_{j}$ 程上式槽準モデル ${ }^{13)}$ 用いる。燃焼 モデルは乱流混命支配の渦消散モデル ${ }^{12)}$ と，多段の化 学反応の影響を調バるめ, Jones ${ }^{17)} の 4$ 段簡略化モ デルと渦消散モデル121 組み合わせたモデルの 2 種類 を用いた。

\section{1 計算対象}

計算対象は，板厚 $16 \mathrm{~mm} \circlearrowleft$ 鋼板上方に一辺 $1.0 \mathrm{~mm} の$ 正方形の出口形状をもつガスノズルを鉛直下向きに配置 し，そのノズルからメタンガス $\left(\mathrm{CH}_{4}\right)$ と酸素 $\left(\mathrm{O}_{2}\right)$ の予 混合燃料を空気中に噴出させ， $\mathrm{CH}_{4}$ ガスの燃焼により形 成される火炎を鋼板に衝突させる衝突噴流火炎である。 火炎温度は極めて短い時間で定常になることから ${ }^{10)}$ ，定 常衝突火炎場として計算した。

燃焼モデルに渦消散モデルを用いた計算では，計算 領域は, 縌 $500 \mathrm{~mm}(\mathrm{x})$, 横 $500 \mathrm{~mm}(\mathrm{y})$, 高さ $96 \mathrm{~mm}(\mathrm{z})$ の 3 次元空間領域を考えた。計算格子は，ノズル出口近 辺と衝突面に近い領域では間隔を小さくした不等間隔格 子とし，ノズル出口と衝突面に近い領域では小さい計算 格子（最小計算格子 $=0.5 \mathrm{~mm}$ ）を生成した. 多段の化学 反応速度支配モデルを用いた計算では, 大気圧での反応 帯の厚みは $1 \mathrm{~mm}$ 以下で、この領域内での化学反応を表 現寸るため，ノズル出口では極めて小さい計算格子を生 成し（最小計算格子 $=0.05 \mathrm{~mm} ） ， 一$ 方で, 計算領域は 縌, 横方向を, 縦 $230 \mathrm{~mm}(\mathrm{x})$, 横 $230 \mathrm{~mm}(\mathrm{y})$ と小さく した，計算モデルおよびノズル形状は Fig.1に示寸。

\section{2 計算条件および境界条件}

ノズル出口での計算条件は既報 ${ }^{10)}$ の実験とほぼ同条 件とし，燃料ガスの噴出速度は実験において測定した 流量から換算した流速 $41.4 \mathrm{~m} / \mathrm{s}$ を与えた.メタンガス $\left(\mathrm{CH}_{4}\right)$ と酸素 $\left(\mathrm{O}_{2}\right)$ の予混合然料の組成、および計算領 域内のガスの初期組成 (Air) は Table2に示寸組成を与 えた。

火炎の温度場計測に，NO 分子を用いた LIF 法を使用 したため燃料拉よび、火炎中にNO分子が存在する. 本 計算で取り扱う化学種は $\mathrm{CH}_{4}, \mathrm{CO}, \mathrm{H}_{2}, \mathrm{O}_{2}, \mathrm{CO}_{2}, \mathrm{H}_{2} \mathrm{O}$, $\mathrm{N}_{2}$, の 7 種であり, $\mathrm{NO}$ 分子を想定していない.このた め, 火炎中の $\mathrm{NO}$ 分子の生成, 消滅は考えてず, 燃料の $\mathrm{NO}$ 分子に関しては $\mathrm{N}_{2}$ に置き換え燃料に添加した.

ガス領域の周囲境界は $\mathrm{z}$ 軸に一垂淔な流体側断面（最上
Table 2 Composition of fuel and air

\begin{tabular}{lcr} 
& & (Unit:\%) \\
\hline Species & Fuel & Air \\
\hline $\mathrm{CH}_{4}$ & 30.4 & 0.0 \\
$\mathrm{CO}$ & 0.0 & 0.0 \\
$\mathrm{H}_{2}$ & 0.0 & 0.0 \\
$\mathrm{O}_{2}$ & 64.3 & 23.2 \\
$\mathrm{CO}_{2}$ & 0.0 & 0.0 \\
$\mathrm{H}_{2} \mathrm{O}$ & 0.0 & 0.0 \\
$\mathrm{~N}_{2}$ & 5.3 & 76.8 \\
\hline
\end{tabular}

面）の格子では，エネルギーに対してのみ自然流出条件 を与える仮想壁を配置し，そのほかの境界は寸べて自然 流山条件を与えた。 また，計算において鋼板内の熱移動 が燃焼流場に影響することから ${ }^{9)}$ ，ガスと鋼板との熱伝 達面に関しては，ガス側において対数則を適応し鋼板の 熱移動を考えた.

なお，実験条件および実験結果の詳細は既報 ${ }^{10)}$ で報 告している.

\section{4. 計算結果と考察}

Fig.2，Fig.3は燃焼モデルに既報 ${ }^{9)}$ で採用した，渦 消散モデルを用いた解析結果と，既報 ${ }^{10)}$ の実験值を比 較したグラフである．Fig.2は水平方向温度分布であり， $\mathrm{z}$ はノズルからの垂直方向距離を示し，(a)がノズル出 口からの距離が $1.3 \mathrm{~mm}$ の面の温度分布で，(b)〜 (c) と 鋼板に近くなり，(d)が鋼板からの距離が $1.5 \mathrm{~mm}$ の面 での温度分布となる．Fig.3はノズル出口をゼロとした 垂直方向温度分布であり，xはノズル中心からの半径方 向距離を表し，(a)がノズル中心軸での温度分布であり， (b),(c) とノズル中心からの距離が大きくなる.

Fig.2(a),(b),(c) でのノズル中心以外の火炎部分, 及 び, Fig.3(b),(c)では, 計算值と実験值はよい一致を示 しており，火炎の幅，火炎の大きさなどの全体の火炎形 状は表現できている。 しかし, 計算値の最高温度はノズ ル中心位置で最高温度を示し，約 $3500 \mathrm{~K}$ となるが，実 験值の最高温度は，ノズル中心位置ではなく、ノズルリ ム（ノズルの厚み部分）付近で, 最高温度を示し, 約 $2500 \mathrm{~K} \sim 2800 \mathrm{~K}$ となる．また，計算結果は実験值で見 られる中心部が寉んだ形をした低温部分がうまく表現で きてお施ず, Fig.2(a)の $\mathrm{z}=1.5 \mathrm{~mm}$ 以外の火炎中心部 $(\mathrm{x}=0$ 付近の領域）において, 温度の低い部分が見られ ない.このことは, Fig.3(a)でも見られ，計算值ではノ ズル出口から急激に温度が上がり，低温度部分がほとん ど見られないのに対し，実験ではノズル出口から 16〜 


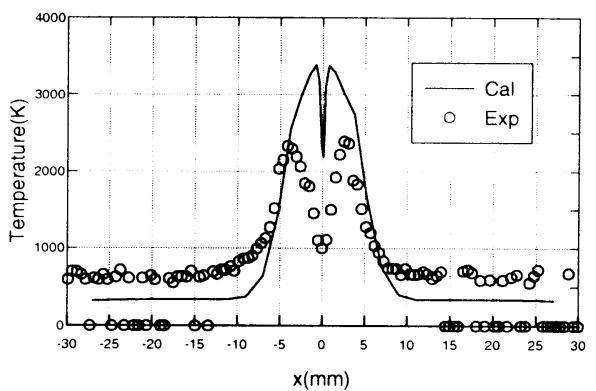

(a) $Z=1.3 \mathrm{~mm}$ (Near the Nozzle exit)

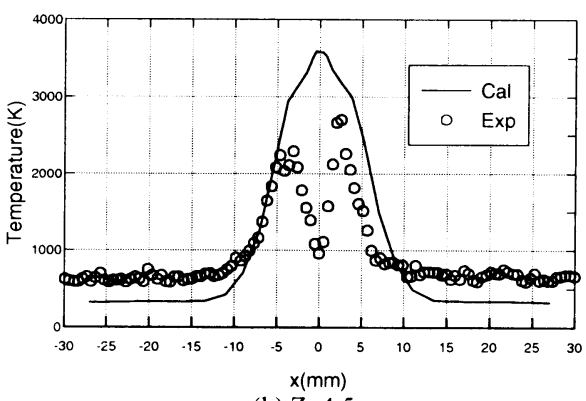

(b) $Z=4.5 \mathrm{~mm}$

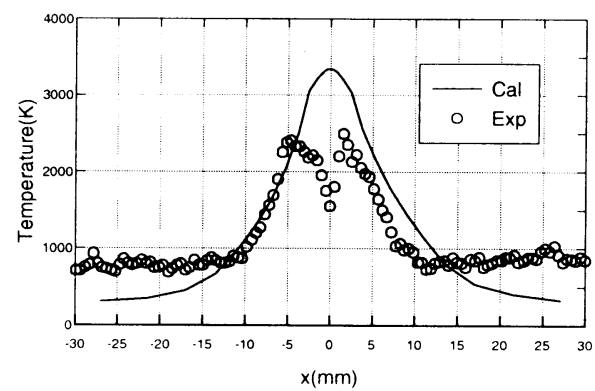

(c) $\mathrm{Z}=14.5 \mathrm{~mm}$

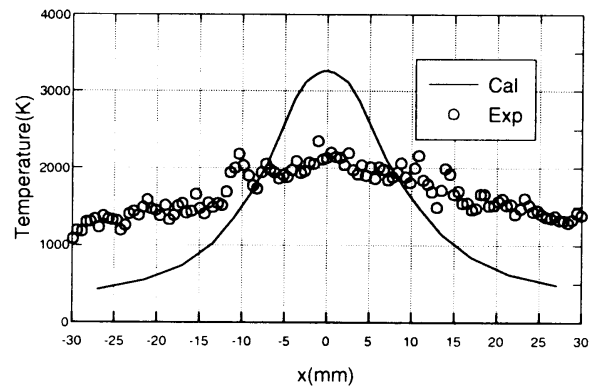

(d) $Z=18.5 \mathrm{~mm}$ (Near the plate surface)

Fig. 2 Experimental temperature distribution of methan gas premixd flame compared with prediction by Eddy dissapation model(horizontal plane)

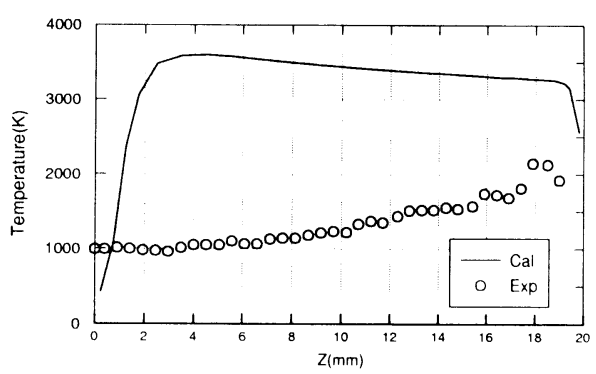

(a) $x=0 \mathrm{~mm}$ (Nozzle center)

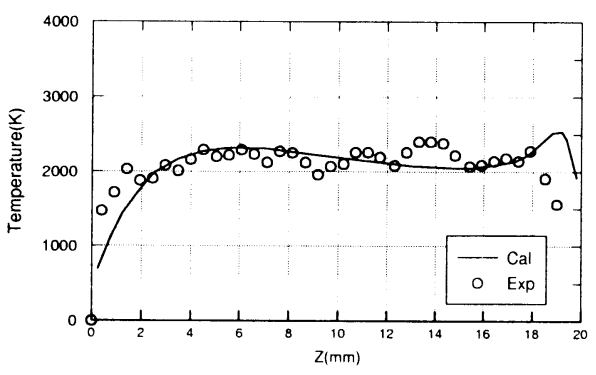

(c) $x=-5 \mathrm{~mm}$

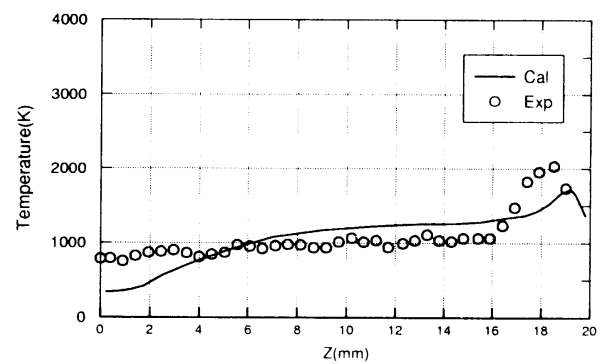

(c) $x=-10 \mathrm{~mm}$

Fig. 3 Experimental temperature distribution of methan gas premixd flame compared with prediction by Eddy dissapation model(vertical line)

$17 \mathrm{~mm}$ 付近まで見られる，全体として温度が高くなるの は，計算において輻射による放熱を無視したことも考え られるが，ノズル付近での燃焼場が異なる原因としては 以下のことが考えられる。i）ノズル中心軸上での燃焼は 化学反応速度に依存しておう, 乱流混合支配ではない。 ii) 渦消散モデルは、総括一段反応が成り立つ燃焼場を対 象としているが，バ一ナ一燃焼では，総括一段反応が成 り立たず，燃料過程で現れろその他の素反応，中間生成 物，燃焼生成物の影響を考慮した多段の反応を考えなけ ればならない，iii）実験で用いたノズルは保炎機構をもっ 
た複雑な形状をしており，このノズルが形成する噴流ガ スの複雑な流れが燃㤝現象に影響を与える。

Fig.4は化学反応速度支配モデルの 4 段簡略化モデル と乱流混合速度支配モモデルである渦消散モデルを組み合 わせたモデルを䏘だ算絬果と実験結果を比較した水 平方向温度分布図で市り，Fig.2 と同様，zはノズルから の垂直方向距離在示し, (a), (b),(c)(d) と鋼板に近くな る. i),ii）の影響を調心゙ろため, 化学反応速度支配モデル と乱流混合速度支配モデルを組み合わせたモデルを用い た計算を行ったが，火炎最高温度は約 $4000 \mathrm{~K}$ と乱流混 合支配モデルだけを用いた時よりも，大きな值を示し， 温度分布形状も一致しない．化学反応を考慮したことに より, 逆に温度分布が高くなったと思われ, 多段の化学 反応と乱流混合を考慮したにも関わらず，乱流混合モデ ルだけを用いた時よりも燃焼場を予測できていない，た だ単に，化学反応速度支配モデルと乱流混合速度支配モ デルを組み合わせただけでは，火炎場を予測することは できない，ノズル中心軸上での燃焼場は化学反応速度依 存とは言い難く, さらに詳細な化学反応を考えたモデル を用いたとしても，その効果は期待できない，そこで, 先に挙げた iii)による影響を考える必要がある.

また，いずれの燃楛モデルを用いても，計算結果実験 結果で見られるような，なだらかな温度分布は見られず， 衝突面近傍での温度は一致しない, 衝突面近傍, 特に ズル中心より離れた領域において, 燃焼反応が起こって いるとは考えられず，この付近での温度分布が一致しな いのは，燃楛モデルが原因とは考えにくい，それよりも， 衝突面近傍での流場が予測できていないのが原因だと思 われる。一般に衝突噴流場では $k-\varepsilon 2$ 方程式および, 壁法 則は適応できないと言犼ているが，本解析では、これ らを用いて解析を行っており，乱流モデル及び，壁法則 の検討が必要である.

本解析においては，既報 ${ }^{9)}$ で採用した渦消散モデルを 用いた計算結果が最も実験結果と良く一致し，火炎の温 度分布の幅など，大まかな火炎形状は表現できている。 衝突噴流場での燃焼は乱流混合速度が支配的であると考 えられ，衝突噴流火炎場の温度場を予測寸るだけである ならば，解析の簡単な，乱流混合速度モデルが適する。 しかし，現状の解析では，計算值の最高温度は実験值の それよりもかなり高い值を示し，ノズル中心部および衝 突面近傍での温度分布が実験結果と一致しないなど, 衝 突噴流火炎場の予測には不十分であり、何らかの改良が 必要である.ここで，さらに詳細な化学反応を考えたモ デルを用いたとしても，乱流混合が支配的な場において その効果は期待できない，また，詳細な化学反応を表現 寸るためには，細かい計算格子が必要となり，乱流場の 実計算において, 詳細に化学反応を考慮した計算は適さ

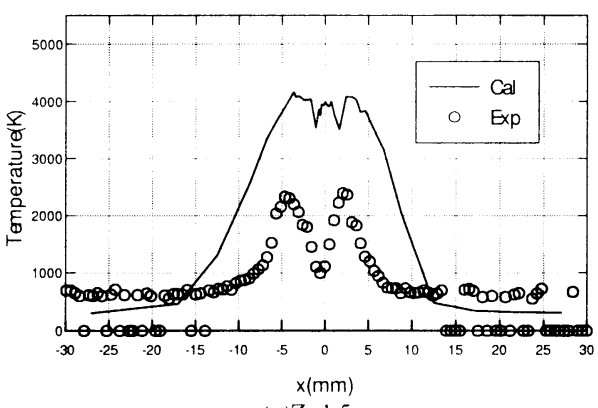

(a) $\mathrm{Z}=1.5 \mathrm{~mm}$

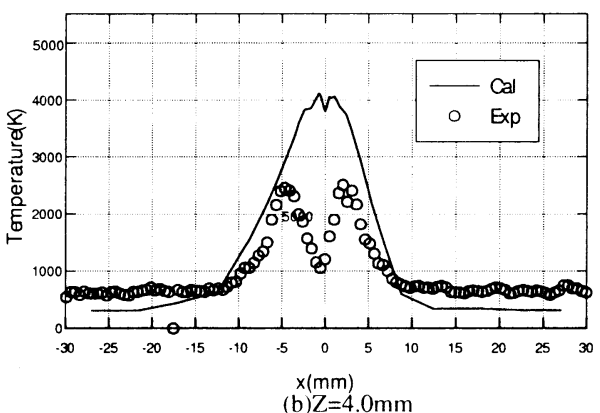

(b) $\mathrm{Z}=4.0 \mathrm{~mm}$

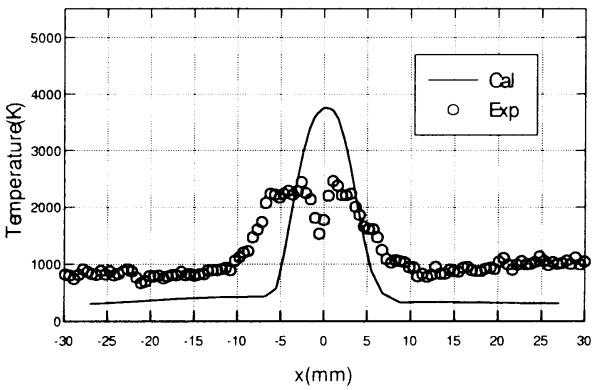

(c) $\mathrm{Z}=15.0 \mathrm{~mm}$

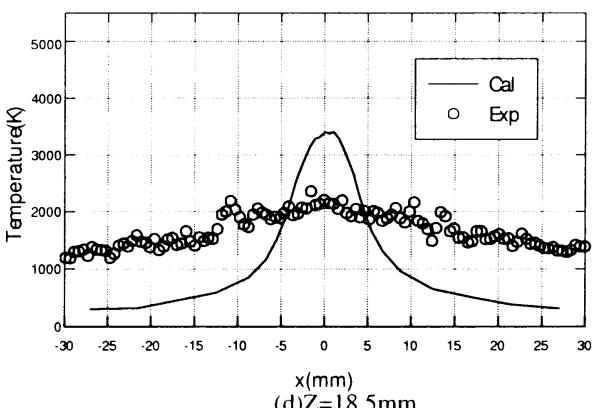

(d) $\mathrm{Z}=18.5 \mathrm{~mm}$

Fig. 4 Experimental temperature distribution of methan gas premixd flame compared with prediction by Eddy dissipation model and Reduced Reaction model 
ない，燃焼モデル以外に計算結果と実験結果が一致しな い原因として，ノズル周辺及び，衝突面近傍の衝突噴流 場の予測が考えられ， $k-\varepsilon 2$ 方程式，壁法則の検討を含め た，衝突噴流場の予測をしたうえで，乱流混合速度支配 モデルの検討を行う必要がある。

\section{5. 結言}

衝突噴流火炎場の燃焼現象は依然解明しておらず，現 行の燃焼モデルで衝突噴流火炎場が推定できるもわかっ ていない， 既報 ${ }^{8) 9)}$ で用いた燃焼モブルの評価を含め. 既存の燃焼モデルのうち、比較的解析の容易なモデルを 用いた計算で，どの程度、複雑な衝突噴流燃焼場計算の 現象を予測できるかを調心゙るため，既報の実験 ${ }^{10)}$ で測 定したバーナーによる点加熱時の火炎温度分布と計算結 果との比較を行った：そして，燃焼モデルの違いによる 温度場の違いを示し, 衝突噴流火炎の燃焼状態に関して の考察を行い，以下のような結論を得た。

1. 衝突噴流場では乱流混合が支配的であり，既報 8)9)で用いた渦消散モデルによる計算はノズル中 心以外での温度分布形状は計算值と実験值はよい 一致を示寸．衝突噴流火炎場の温度場を予測寸る 場合の、本研究の目的に合った燃焼モデルは，詳 細反応を考えた化学反応速度支配モデルではなく， 解析の簡単な，乱流混合速度モデルが適寸る。

2. 現行の渦消散モデルでは，計算值の最高温度は八 ズル中心軸上，衝突面近傍での温度分布が実験結 果と一致しない，計算結果と実験結果が一致しな い原因の多くは，ノズル周辺及び，衝突面近傍の 衝”突噴流場を正しく予測できないためだと思われ， $k-\varepsilon 2$ 方程式，壁法則の検討を含めた，衝突噴流場 の予測をしたうえで，乱流混合速度支配モデルの 検討を行う必要がある。

\section{謝辞}

本研究の一部は科学研究費補助金基盤研究 (B) (2) 課題 番号 12450401 (研究代表者 富田康光) の補助を受けた ことを付記し，関倸各位に御礼申し上げます。

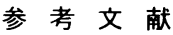

1）上田幸雄,村川英一,Rashwan A.M.: “計算機支援 板曲げ法案自動作成システムの開発（第 1-4 報）” 日本造船学会論文集, 170-174 (1991-1993)

2）石山隆庸, 丹後義彦, 中村祐介：“FEMを応用した 線状加熱自動化の実用化研究” 日本造船学会論文 集, 183 (1998) pp.335-342
3）野本敏治, 大森拓也, 須藤拓, 榎沢誠, 青山和浩, 斎藤 正雄: “線状加熱板曲げ加工シミュレー夕い開発” 日本造船学全論文集, 168 (1990) pp.529-537

4）野本敏治，武市详司，将基孝一朗，青川和浩，榎沢誠。 斎藤正雄：“向门縮文を考慮した撓鉄作:業朋シミュ レータの開発”日本造船学会論文集，170（1991） pp.599-607

5）辻勇，奥村耕之：“鋼材の線状加熱板曲げ加工に二関寸 万研究” 西部造船学会会報, 76 (1988) pp.149-160

6) 寺崎俊夫, 北村信男, 中井雅之：“線状加熱加工にお ける熱サイクルの予測式”西部造船学会会報，99 (1999) pp.321-329.

7) 富田康光, 橋本聖史, 大沢直樹, 吉川光昭, 萬雅史, 新

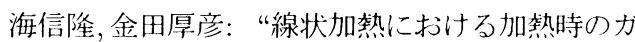
又流場の近似解法に関寸る研究” 日本造船学会論文 集, 184 (1998) pp.469-476

8) 富田康光, 橋本聖史, 大沢直樹, 澤村淳司, 新海信隆: “線状加熱における燃焼流場の数值シミュレーショ ン”関西造船協会誌, 232 (1999) pp.155-161

9) 澤村淳司, 富田康光, 橋本聖史, 大沢直樹, 新海信隆: “線状加熱における燃焼流場から鋼板への熱移動 に関寸る研究” 日本造船学会論文集, 187 (1999) pp.373-381.

10）新海信隆,富田康光, 大沢直樹, 橋本聖史, 澤村淳司: “線状加熱に打ける熱源移動時の加熱ガス流場の解 析方法に関寸万研究” 関西造船協会誌, 234 (2000) pp.229-235.

11）安田俊彦: “流動, 伝熱, 燃焼数值解析の基礎から最 新のシミュレーション技術まで” 日本機械学会第 230 回講習会教材, (1998) pp.19-24

12) Magnussen,B.E.,Hjertager,B.H.: "On Mathematical Modeling of Turbulent Combustion with Special Emphasis on Soot Formation and Combustion" Proc.16th Symp.(Inter) on Combustion, (1976) pp.719-729

13) Launder,B.E.,Spalding,D.B.: "The Numerical Computation of Turbulent Flows" Comp.Meth.Appl.Mech.Eng., 3 (1974) pp.269-289

14) Bird,R.B., Stwart, W.E., Lightfood, E.N.: "Transport Phenomena" John Wiley \& Sons. $(1960)$ 
15) Stull.D.R.. Prophet,H.: "JANAF ThermoChemical Tables (2nded.)" U.S. Dept. of Commerer. Mashington (1971)

16) Westbonk.('K..Dryer.F.L.: "Simplified reacetion merhanisms for the oxidation of hreho(arbon fuels in Hames" Combust. Sci. Torhnol..2T ( 1981$)$ p). $.31-43$

17) Jones. I'.I'..Lindastedt,R.P.: "Global Roaretion Schemes for Hydrocarbon Combustion" Combust. Flame,73 (1988) pp.233-249

18) Patanker.S.V.: "Numerical Heat Transfer and Fluid Flow" Hemisphere Publishing Corporation, (1980)

19) D.G.Lilleyt,D.L Rhode: "A Computer Code for Swirling Turbulent Axisymmetric Recirculating Flow in Practical Isothermal Combustor Ceometries" NASA Contractor Report.3442 (1982) 